УДК 94(476)-0565.2 «1944/50»

\title{
ЕВРЕИ БССР В 1944-1950-е ГГ. ПРОБЛЕМА ЭТНИЧЕСКОЙ САМОИДЕНТИФИКАЦИИ В УСЛОВИЯХ СОЦИАЛЬНОЙ ТРАНСФОРМАЦИИ ОБЩЕСТВА
}

\author{
Е. С. РОЗЕНБЛАТ
}

\author{
Брестский государственный университет имени А. С. Пушкина, г. Брест, Беларусь
}

В первое послевоенное десятилетие происходили процессы социальной трансформации белорусского общества: шла урбанизация, происходил отток населения из деревень и местечек в города. Отмечались особенно высокие темпы урбанизации еврейского населения БССР: движение в районные и областные центры было обусловлено особенностями социальной и профессиональной структуры еврейского населения, учёбой еврейской молодёжи в вузах (в первые послевоенные годы евреи составляли до $17 \%$ студентов высших учебных заведений республики), престижностью проживания в крупных населенных центрах. В определенной степени высокие темпы урбанизации еврейского населения БССР определялись уничтожением еврейских общин Белоруссии в годы войны. В 1959 г. около 1/4 части евреев республики проживало в Минске. Размещение еврейского населения оказывало самое прямое воздействие на ускорение темпов аккультурации и ассимиляции. Но с другой стороны - такая концентрация еврейского населения являлась способом преодоления дисперсности, способствовала поддержанию внутринациональных связей.

Во второй половине 1940-х - 1950-е годы в составе еврейского населения Белоруссии произошли значительные изменения. Еврейская диаспора стала более однородной: практически исчезло её деление на «западников» и «восточников», сбалансировались настроения, ожидания и стремления, определился основной путь развития - ассимиляция в сочетании с сохранением идентичности.

Удельный вес евреев, составлявших до войны около $10 \%$ всего населения республики, резко снизился. По данным переписи 1959 г., в БССР проживало 150,1 тыс. евреев, что составляло 1,9 \% населения республики, при этом в восточной части Беларуси было сосредоточено абсолютное большинство евреев - 140 тыс. чел. [1, s. 114].

Одним из последствий Холокоста в Белоруссии стало изменение не только количественных показателей, но и качественных. Годы испытаний, пережитое в оккупации, на фронте и эвакуации, потеря близких, необходимость начинать жизнь сначала - всё это не могло не отразиться в определенной степени на психике, поведении, восприятии окружающего евреями. Это были люди, имевшие колоссальный опыт выживания, приспособления к окружающим их обстоятельствам и людям, высокий личностный коэффициент преломления факторов внешней среды.

В последний год войны и первые послевоенные годы произошел своеобразный культурно-национальный всплеск «еврейской жизни», признаками которого были стремление еврейского населения регистрировать общины, открывать синагоги, еврейские культурные центры [2, с. 259-260]. В 1948 г. начался новый этап в истории евреев в СССР. Белорусские евреи в полной мере почувствовали изменение вектора в политике советской власти по «еврейскому вопросу». Оно ознаменовалось убийством С. Михоэлса в январе 1948 г. в Минске, вытеснением евреев из партийного и советского аппарата, закрытием ЕАК, кампанией по борьбе с «безродными космополитами», отказом регистрировать еврейские общины и открывать синагоги, закрытием в марте 1949 г. Белорусского государственного еврейского драматического театра в Минске, еврейских издательств и библиотек, репрессиями в отношении еврейских писателей и поэтов, «делом врачей». Белорусские евреи почувствовали отчуждение со стороны государства и общества. Усилился бытовой антисемитизм. Свою роль в этом сыграли давние традиции, кроме того, почва была удобрена сначала нацистской пропагандой, условиями оккупации, а затем тяжелой социальноэкономической послевоенной ситуацией. Появились новые сюжеты в антисемитской мифологии. Одним из них стал миф о покорных евреях, которые «как овцы» шли на гибель и не предпринимали попыток спастись. Ещё более широкое распространение имел стереотип о евреях, которые «отсиделись в эвакуации в Ташкенте». Симптоматичным стало проявление «аппаратного» антисемитизма. 
После войны у еврейского населения Белоруссии, сохранявшего деление на «западников» и «восточников», были различные возможности организовать свое будущее. «Западники» имели права на выезд как бывшие граждане Польши и активно пользовались ими. На протяжении 1944-1946 гг. подавляющее большинство депортированных из западных областей Белоруссии евреев выехали за границу, далее их маршруты пролегали поразному: Польша, другие европейские страны, США, Канада, Израиль. У «восточников» не было альтернативы оставаться или эмигрировать. Вопрос о перспективах для них сводился к дилемме сохранить свою идентичность или пойти по пути дальнейшей ассимиляции.

В результате сложившихся исторических условий происходила дальнейшая трансформация еврейского общества Белоруссии. Белорусское еврейство конца 1940-х начала 1950-х годов существовало как особая и вместе с тем интегрированная часть советского общества. Еврейский конформизм как форма приспособления к идеологической ситуации и к принятым нормам поведения окружающих выражался в различных формах самоотчуждения [3, с. 69].

Происходила стремительная утрата еврейского языка, культуры и традиций. Динамика, которая иллюстрирует данную тенденцию, выглядит следующим образом: по официальным данным переписи 1926 г. 90,7 \% евреев БССР признало еврейский своим родным языком, в 1939 г. $-41 \%$, а в 1959 г. $-21,9 \%$ [4, с. 74,128$]$.

Как правило, евреи Беларуси выбирали компромисс: приобретаемая внешняя форма соответствия окружающим условиям сочеталась с глубинным осознанием своей принадлежности к еврейскому народу [5, с. 53].

Евреи мимикрировали, старались не выделяться, не отличаться, быть такими же, как окружающие. В инонациональной среде только немногие могли противостоять ассимиляции. Однако в большинстве случаев евреям не давали забыть об их происхождении окружающие. Чтобы ассимиляция евреев стала реальностью, стремление ассимилироваться должно было дополняться таким же желанием среды ассимилировать их. Само государство, ставя задачу принудительной ассимиляции евреев (как и многих других национальных меньшинств), антисемитскими кампаниями 1940-х годов сделало эту ассимиляцию невозможной, выделив евреев как объект антисионистской пропаганды и репрессий. Результатом проводимой политики явилось то, что в конце 1940-х годов белорусские евреи начинают утрачивать черты национальной общности, постепенно происходит распад внутренних коллективных связей (на уровне религиозных общин, еврейских общественных и культурнопросветительских организаций). Проблема самоидентификации решалась на межличностном уровне в контактах «еврей - еврей» и «еврей - нееврей».

\section{Литература}

1. Eberhardt, P. Przemiany narodowościowe na Białorusi / P. Eberhardt. - Warszawa, 1994. - $182 \mathrm{~s}$.

2. Смиловицкий, Л. Евреи Беларуси. Из нашей общей истории (1905-1953) / Л. Смиловицкий. - Минск : Арти-Фекс, 1999. - 360 с.

3. Дамерская-Цигельман, Л. Об идеологической мотивации различных поколений активистов еврейского движения в СССР в 70-х годах / Л. Дамерская-Цигельман // Вестник еврейского университета в Москве. - 1994. - № 1 (5). - С. 63-90.

4. Эбэрхардт, П. Дэмаграфічная сітуацыя на Беларусі: 1897-1989 / П. Эбэрхардт. - Менск : Беларускі Фонд Сораса, 1997. - 277 с.

5. Роланд, Б. Искусство требует жертв / Б. Роланд // Мишпоха. - 1997. - № 3. - С. 48-63.

В статье рассматриваются количественные и качественные изменения в составе еврейского населения Белоруссии во второй половине 1940-х - 1950-х годов двадцатого века. Обозначен процесс трансформации еврейского общества Белоруссии, обусловленный процессом урбанизации, изменением социальной и профессиональной структуры еврейского населения, стремительной утратой еврейского языка, культуры и традиций.

The article examines the quantitative and qualitative changes in the composition of the Jewish population of Belarus in the second half of the 1940s and 1950s. The process of transformation of the Jewish society of Belarus, due to the process of urbanization, the change in the social and professional structure of the Jewish population, the rapid loss of the Jewish language, culture and traditions, is marked. 